\title{
Job Shadow Day 2000
}

\author{
Recruiting to the profession
}

\author{
by Margot Sutton
}

$0^{\prime}$

n February 2, 2000, the divisions of the ALA joined forces with associations across America in support of Job Shadow Day, an event that partners junior high, high school, and college students with workplace mentors.

ALA Divisions Job Shadow Day is a new initiative for ACRL and holds great promise as a strategy to improve recruitment into our profession.

ACRL applauds the participating libraries for introducing more than 125 young people to the profession of librarianship and helping them understand firsthand what librarians do.

\section{Sharing our experiences}

To help you plan for the 2001 ALA Divisions Job Shadow Day, ACRL would like to share summaries from six of this year's participants. We hope their stories

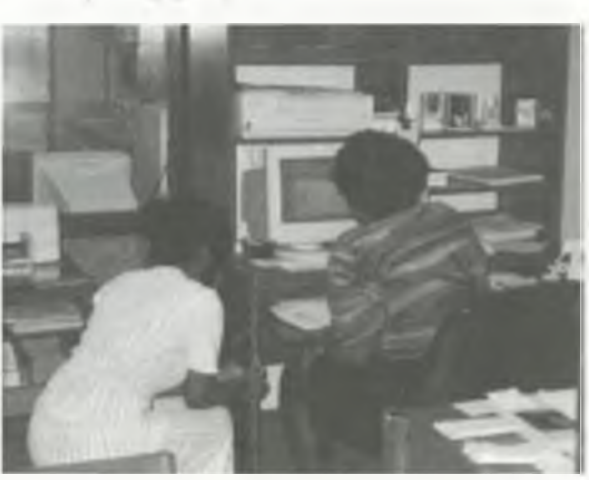

A shadow listens intently to a Francis Marion University staff member. and five students from Hannah-Pamplico Middle School.

After a brief introduction to the library and a guided tour, the shadows, who were chaperoned by their high school librarian, were assigned to library hosts. The shadows helped check out books to patrons, shelved books, searched the online database, filled interlibrary loan requests, and examined archive materials.

After lunch, the day concluded with a casual wrap-up. Linda Becote, catalog librarian and Job Shadow Day coordinator, commented that "Job Shadow Day was a smashing success at the James A. Rogers Library and a day enjoyed by all. We look forward to doing it again next year!"

- Northern Arizona University (NAU). NAU hosted three students during their shadow day. NAU librarians showed the shadows how to help students who visited to become involved in the event and encourage your library to participate in this exciting initiative.

- Francis Marion University-Florence, South Carolina. The entire staff of the James A. Rogers Library hosted five students from Hannah-Pamplico High School the reference desk and emphasized that answers and information can be found in a variety of ways and formats.

The shadows were then put to the test when they were instructed to find similar materials in the print collection, on the computer databases, and on the Internet.

\section{About the author}




\section{I learned that the library is not}

just books and being quiet, but it

is about learning new things.

-Kia Drake, a ninth grader

attending Job Shadow Day

at Wayne State University

- Queens Borough Public Library. Library Director Gary Strong kicked off the day by greeting the 27 high school students participating in the shadow day. The shadows listened to presentations from a young adult librarian and the film/video division, participated in a tour of the gallery, and then were paired up with librarians.

The shadows spent $1 \frac{1}{2}$ hours with librarians at both public service and non-public service worksites. During lunch, the shadows' received applications to apply for page positions and volunteer work. Nick Buron, coordinator of young adult services and Job Shadow Day coordinator, stated that "the shadows' enthusiasm was very special and, combined with the dedication of the Queens Borough librarians, made for a very positive program."

- University of Illinois at Chicago (UIC). The Richard J. Daley Library at UIC hosted six students from the William Jones Academic Magnet High School.

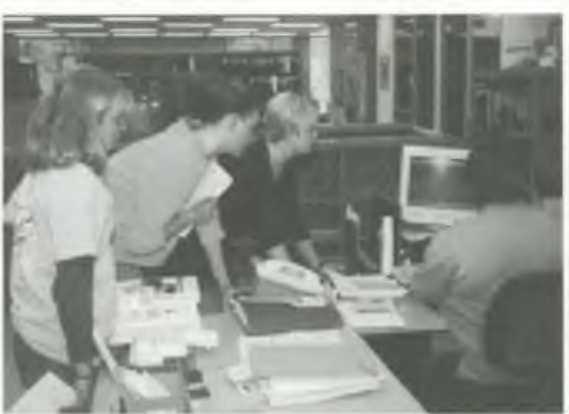

Students from Price Lab School in Cedar Falls, lowa, visit Rod Library at the University of Northern lowa.

Nick Buron, coordinator of Young Adult Services, shows shadows the Young Adult room.

large-group sessions. The first session presented an overview of what an academic library is; another session explained the documents department; and the final session explored computers, systems, and electronic resources in the library. The shadows spent the other half of the time one-on-one with a mentor, in the mentor's work area, or visiting specific parts of the library.

Linda Naru, director of advancement and UIC Job Shadow Day coordinator, provided this planning tip: Prior to the shadow day, librarians should contact their local press for newspaper and television coverage.

- University of Northern lowa-Cedar Falls. Job Shadow Day at Rod Library was adapted to accommodate the fact that the two participating Job Shadow Day hosts were library administrators whose jobs and days The Jones high school librarian accompanied the students.

All of the participating shadows work in their school library and belong to the school's library club. Four of the UIC mentors were reference librarians, one was a systems librarian, and one was a personnel librarian.

The librarians adapted the suggested schedule in the planning notebook to a halfday program (three hours), since the students were not free to spend the entire school day at UIC. About half the time was spent in three

don't readily reflect the "average" librarian's job. The librarians made sure the shadows understood administrative responsibilities, but also had shadows spend time in the various departments of the library to see many of its functions.

Marilyn Mercado, associate dean of library services and Job Shadow Day coordinator, stressed that shadow day participants realize they are able to modify and tailor their day's

(continued on page 311) 


\section{FOCUS ON SERIALS}

The recent mergers and acquisitions taking place in the industry have caused some concern and questions to arise regarding the current situation of serials vendors. Several members of the library community have asked EBSCO to explain our position amidst all these changes, and we are pleased to do so.

We're stable, reliable and here to stay. This well describes EBSCO's position now, in the past and in the future. We're here, doing exactly what we planned to be doing before any of these major changes to our competitors were announced. Our position hasn't changed and won't change. EBSCO is a financially strong, stable company with a Dun \& Bradstreet financial strength rating of 5A1, the highest possible. We are privately held; we make decisions for the benefit of our customers and employees. We listen to our customers and determine what we need to do to grow our company and our services based on our long-term mission of maintaining profitability while providing the best service possible for our customers, as we know the two are inextricably tied.

Customer service is our strength. Throughout EBSCO's history exceptional customer service has been our hallmark. We've combined good people with good systems and backed them both by a strong commitment to serving our customers' needs. Our managers, field representatives, account services managers and the customer service representatives who handle the daily contact with and problem solving for our customers all operate at the regional office level - always have, always will, because it works. We are sensitive to the unique requirements of individual libraries and take a serious role in the management of our customers' serials collections. The same concerns guide the development of our electronic services. Just because a process is automated doesn't mean it has to operate like a cookie cutter.

Our plans are simple - to serve our customers' needs. We do this through partnerships with customers, publishers, other vendors and the library community as a whole. EBSCO's long-term goal is to offer a true "one-stop" source for a library user's complete research needs. As we further enhance our electronic services, we recognize that technology must not impose on - and certainly not take the place of - the personal service for which EBSCO is known. Our immediate objective is continuing the integration of our Web-based services. Entirely new services are also strategically scheduled for months and years to come. And we won't bring those to the marketplace until they've been thoroughly thought through, developed and tested.

So this is our position. We believe our management philosophy, our network of offices and personnel, our tradition of excellence and our financial strength all necessary to make and honor commitments - assure us and our customers of success.

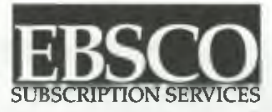

A part of the EBSCO Information Services group.

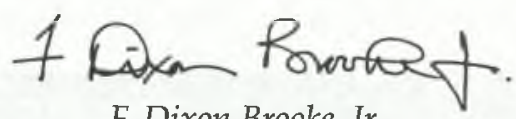

F. Dixon Brooke, Jr.

Vice President, General Manager

Telephone 205/991-6600 • Fax 205/995-1636 • http:/ /www.ebsco.com 


\section{New Releases from APA Books}

\section{Videos in Psychology:}

A Resource Directory

This new reference source lists almost 1,000 summaries of videos with psychological content, as well as contact information for obtaining the video. 2000. About 216 pages. Softcover.

APA Member/Affiliate \& List: \$14.95

Item \# 4310560; ISBN: 1-55798-709-2

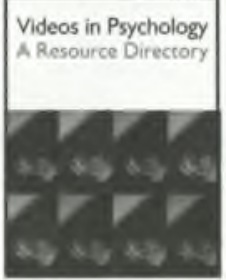

\section{Psychodynamic Perspectives on}

\section{Sickness and Health}

Edited by Pasl Raphael Duberstein and Joseph M. Masling

2000. About 456 pages. Hardcover.

APA Member/Affiliate: $\$ 39.95$; List: $\$ 49.95$

Item \# 431634A; ISBN: 1-55798-668-1

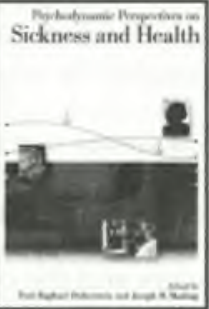

The Psychology of Couples and Illness:

Theory, Research, and Practice

Edited by Karen B. Schmaling and Tamara Goldman Sher

2000. About 400 pages. Hardcover.

APA Member/Affiliate: \$39.95; List: \$49.95

Item \# 431745A; ISBN: 1-55798-649-5

\section{Executive Coaching:}

Developing Managerial Wisdom in a World of Chaos

Richard R. Kilburg

2000. About 272 pages. Hardeover.

APA Member/Affiliate: $\$ 34.95 ;$ List: $\$ 39.95$

Item \# 431744A; ISBN: 1-55798-648-7
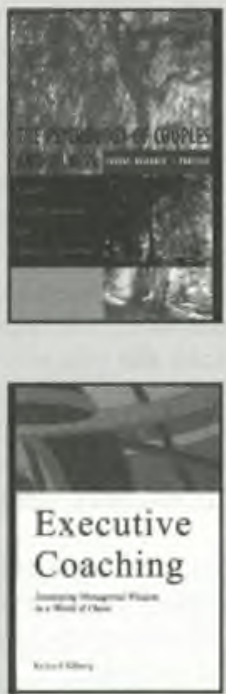

\section{1-800-374-2721 www.apa.org/books}

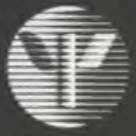


transportation in Europe, and lodging and board for a period not to exceed 14 consecutive days.

Larson plans to use the grant for travel to Rome and Paris to gather research at the Vatican Library and Parisian archives for his study, "Documenting the Dissemination of the Gregorian Calendar Reform in France During the Wars of Religion."

John Cullars, chair of the Western European Specialists Section (WESS), said, "Jeffry Larson's is a fascinating bibliographical study that will be of interest to historians of the Reformation and Counter-
Reformation and of Renaissance France, including historians of science and of social attitudes, the librarians who assist them, and those who ask themselves, "Where did the missing ten days of our calendar go?'"

He has served as the editor of the Romance Language section of Reference Reviews Europe, and is the former editor of the WESS Newsletter.

The award will be presented at the WESS General Membership Meeting on Monday, July 10 , at 11:30 a.m. during the ALA Annual Conference in Chicago.

\section{("Job Shadou' Day . . " continued from page 296)}

activities to a format that best works for them.

- Wayne State University (WSU)-Detroit. WSU's undergraduate library hosted 60 middle- and high-school students. This initiative is especially important for the Detroit area since current hiring data revels that minorities only represent $9 \%$ of academic librarians and less than $12 \%$ of all students enrolled in $\mathrm{Li}-$ brary Science programs.

The students spent the better part of the day at the library. The librarians at the Undergraduate Library thought this was such a successful event that they are considering presenting their summary in an extended format, such as a poster session at an ALA or ACRL conference.

Job Shadow Day participant Kia Drake, a ninth grader at Detroit's Martin Luther King high school said, "When MLKing's 9th grade CPLA (College Prep Liberal Arts) stuclents attended the Wayne State Undergraduate Library trip, at first I thought it was going to be boring, but when we got there it was interesting to see all of the college students at work. I learned

(Why am I dreaming

page 301)

end. (Since you change the page, it is easy for others to suggest work for you.)

Finding a balance between being overwhelmed in Webmaster land, and actually thoughtfully improving the page is a difficult part of the job. Check out our "permanently unfinished product" at http://library.uncwil. edu. that the library is not just books and being quiet, but it is about learning new things. I learned how the library runs all of the time and how much fun it would be to work there. I had fun playing on the Internet looking for different references. This trip was fun and I would love to go again."

\section{It's not too early to start planning}

As the ALA Divisions Job Shadow Day continues to develop, we hope that the groundwork shared by this year's participants will be useful for an increasing group of library participants.

ACRL encourages all libraries to start planning now for next year's Job Shadow Day on February 2. The Job Shadow Day Planning Kit developed for this year's participants will be updated for 2001 and will remain on our Web site at www.ala.org/acrl/ jobshadow.pdf.

Questions should be directed to Margot Sutton, ACRL Job Shadow Day coordinator, (800) 545-2433, ext. 2522; e-mail: msutton@ ala.org.

Although we have chosen to take a slightly humorous tack on this subject (we know, you are uncertain of the humor), it is really a growing area of service and design in every academic library.

Please share with the greater library community your stories of Web successes and failures so that all can benefit from your words of wisdom. 